\title{
Article \\ Experimental Assessment of Friction Coefficient in Deep Drawing and Its Verification by Numerical Simulation
}

\author{
Emil Evin ${ }^{1}$, Naqib Daneshjo ${ }^{2}$, Albert Mareš ${ }^{1} \mathbb{D}$, Miroslav Tomáš ${ }^{1}$ and Katarína Petrovčiková ${ }^{3, *}$ \\ 1 Faculty of Mechanical Engineering, Technical University of Košice, Mäsiarska 74, 04001 Košice, Slovakia; \\ emil.evin@tuke.sk (E.E.); albert.mares@tuke.sk (A.M.); miroslav.tomas@tuke.sk (M.T.) \\ 2 Faculty of Commerce, University of Economics in Bratislava, Dolnozemská Cesta 1, \\ 85235 Bratislava, Slovakia; daneshjo47@gmail.com \\ 3 Faculty of Business Economy with seat in Košice, University of Economics in Bratislava, Tajovského 13, \\ 04130 Košice, Slovakia \\ * Correspondence: katarina.petrovcikova@euba.sk
}

Citation: Evin, E.; Daneshjo, N.;

Mareš, A.; Tomáš, M.; Petrovčiková,

K. Experimental Assessment of Friction Coefficient in Deep Drawing and Its Verification by Numerical Simulation. Appl. Sci. 2021, 11, 2756. https://doi.org/10.3390/app11062756

Academic Editor: Jörg Wallaschek

Received: 14 February 2021

Accepted: 17 March 2021

Published: 19 March 2021

Publisher's Note: MDPI stays neutral with regard to jurisdictional claims in published maps and institutional affiliations.

Copyright: (c) 2021 by the authors. Licensee MDPI, Basel, Switzerland. This article is an open access article distributed under the terms and conditions of the Creative Commons Attribution (CC BY) license (https:/ / creativecommons.org/licenses/by/ $4.0 /)$.

\begin{abstract}
The friction coefficient in the simulation of stamping processes should be defined. Modern simulation software allows its definition as constant or its dependence on pressure or temperature. It is also useful in stamping processes to define different values in different regions, as it often reflects the nature of deformation process. This article deals with the regression and analytical models commonly used to determine the friction coefficients in specified areas of the stamping process. Analytical models were verified by an experimental strip drawing test under the same contact conditions. Steel sheets for the automotive industry were used in experiments and simulationsextra deep drawing quality DC 05 and austenitic stainless steel AISI 304. Friction coefficients were also evaluated when the cup test was performed. A regression model of drawing to the blankholding force was applied to the results. Conformity of friction coefficients when measured by cup tests and strip tests was confirmed. The values of the friction coefficient reached from the experiment were applied in FEM simulation software.
\end{abstract}

Keywords: deep drawing; strip drawing test; cup test; friction coefficient; numerical simulation

\section{Introduction}

The development of the field of sheet metal processing by sheet metal forming is determined primarily by the automotive industry. The manufacturability of pressings made from steel sheets is given by their formability. There are many parameters influencing the formability: material properties [1], forming die geometry and process parameters (blankholder pressure, punch and die radii, etc.) [2], punch and die contact surface microgeometry, and the lubricant applied $[3,4]$. The last mentioned and the steel sheets' surface microgeometry are included in the term 'friction conditions', which describe the contact between objects from the view of tribology and they also influence the steel sheet formability [5,6].

Friction on contact surfaces between the punch, die, and blank depends on their surface microgeometry, blank velocity during stamping, type and properties of lubricant, contact pressure on asperities, etc. These factors do not act independently, but interact with each other [7]. Due to the fact that friction conditions are not the same over the entire contact area, the values of the friction coefficients are not constant over the entire contact area of the blank with the punch and die. The local contact conditions can vary widely.

Types of contact between the steel sheet surface and the die surface in stamping processes (deep drawing, stretching, and bending) can be characterized as shown in Figure 1. When the blank is drawn between the blankholder and the die, it is not deformed. This type of contact (Figure 1a) occurs during bending or deep drawing of squared stamped parts in their straight parts. On the drawing edge, Figure $1 \mathrm{~b}$ (die radius), the blank is bent 
and drawn into the die. Thus, deformation occurs in the radial direction only. It occurs in the straight parts of squared stamped parts or in bending as well. In the corner of the stamped part, Figure 1c, deformation in the radial direction is preserved and, additionally, deformation in the tangential direction arises, which is caused by drawing the blank into the die. The change in the microgeometry of the blank surface can be observed when the deformation is large enough [2,5].

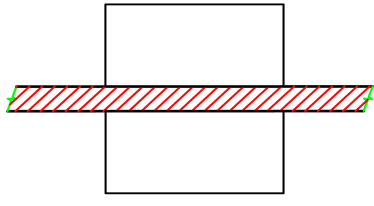

(a) Under the blankholder (straight die)

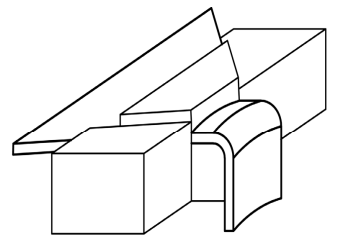

(d) On the drawing radius (curved die)

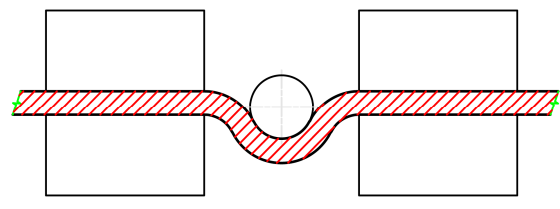

(g) Stretching of blank

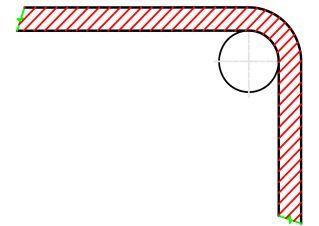

(b) On the drawing radius (straight die)

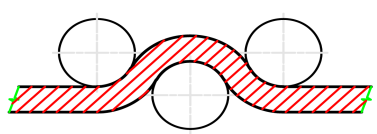

(e) On drawing beads

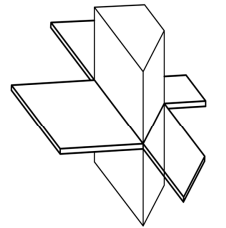

(c) Under the blankholder (curved die)

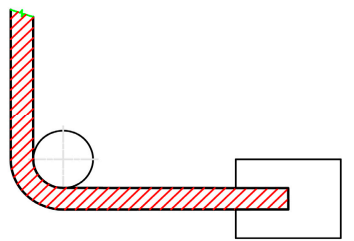

(f) On punch radius

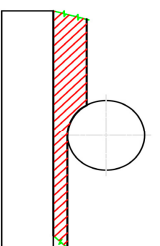

(h) Wall calibration

Figure 1. Types of contacts at deep drawing.

Similarly to Figure $1 \mathrm{~b}$, when material is drawn over die radius but in the corner of stamped part, as it is shown in Figure 1d, the blank is deformed in both radial and tangential directions. As a result, the total drawing forces are higher. When square (or rectangular) parts are drawn, drawing beads (Figure 1e) are used in their straight parts in order to equal the material plastic flow between the straight parts (high flow) and in the corners (low flow) of stamped parts. This is caused by additional bending of material when drawn through draw beads. The loading of contact surfaces on the punch radius and type of contact is depicted in Figure 1f. In this area, higher friction has a positive effect due to increasing the stamping force, which is transferred by friction between the punch and blank. The type of contact in Figure $1 \mathrm{~g}$ represents the stretching of the blank, while the type of contact in Figure $1 \mathrm{~h}$ reflects the calibration of the stamped part.

Nowadays, formability prediction is done by numerical simulations of stamping by using software based on the finite elements method [8]. By simulating forming, process designers can optimize the process parameters, die and punch geometry, friction, etc. However, the accuracy of forming simulations depends mainly on input values-if inaccurate boundary conditions are set, then the results of the prediction of formability characteristics obtained by numerical simulation do not show the required agreement with the results obtained experimentally. Since the friction has the biggest impact on sheet formability, it is important to define the friction coefficient on the die contact surfaces.

The importance of the friction influence on the forming process is also evidenced by the number of authors who deal with this issue, because the issue of friction during forming 
is very complex. The friction coefficient at forming are measured by tests. Sniekers [9] improved the quality of the calculated friction coefficient by better method of data processing when recorded from radial strip drawing test. Vollertsen and Hu optimized the analytical model for determination of the friction coefficient in deep drawing with respect to the distribution of the contact pressure at the drawing radius [10]. Kirkhorn et al. [11] improved the conventional test based on parallel strip drawing by modifying the tester to allow a controllable speed and normal load during experimenting, a tool size variable over a wide range, and direct force measurement. Wang et al. [12] experimentally studied the friction coefficient in sheet metal forming. They developed a friction coefficient measuring apparatus based on the drawing die of the cylindrical parts. According to the relationship between the drawing force and the stroke, the linear fitting algorithm of the friction coefficient was given based on the least squares method. Hol et al. [13] presented advanced friction model for large-scale forming simulations based on the surface changes on the micro-scale. They developed the friction model which accounts for the change of the surface texture on the micro-scale and its influence on the friction behavior on the macro-scale. After implementing the friction model in a simulation, they reached a realistic distribution of the coefficient of friction depending on the local process conditions. Trzepiecinski and Fajkiel [14] studied the effect of sheet deformation on the change of the surface roughness parameters and friction coefficient in the strip drawing test. They found that the friction coefficient determined for all pre-strained samples decreased with increasing nominal pressure of rolls under both dry and lubricated conditions. An increase in the plastic deformation of sheets under the uniaxial tensile stress state caused a nearly linear increase in the value of basic amplitude parameters of surface roughness. Wen-yu et al. [15] analyzed the effect of the friction coefficient on the deep drawing of aluminum alloy at elevated temperatures experimentally and numerically. Results showed that the friction coefficient and lubrication position significantly influenced the minimum thickness, the thickness deviation, and the failure mode of the formed parts. Temperature-induced friction effects in sheet metal forming was the subject of study by Kott et al. [16] as well. Trzepiecinski and Lemu summarized the methods used to describe friction conditions in conventional sheet metal forming and incremental sheet forming [17]. Based on searching many databases, they described and discussed the main disadvantages and limitations of the methods of modeling the friction phenomena in specific areas of the material to be formed.

The aim of the article is to determine the friction coefficient in different regions of the die during the stamping process-under the blankholder and on the die radius. Experiments were performed on two types of steel with different surface and material properties. Data recorded from the strip drawing test were processed by analytical models to calculate the friction coefficients. These results were set in simulation software and friction coefficients were determined by regression analysis the results of the cup test.

\section{Methodology of Experimental Research}

Two steels were used during experiments: uncoated cold rolled extra deep drawing quality DC 05 with thickness $\mathrm{a}_{0}=0.8 \mathrm{~mm}$ and austenitic stainless steel AISI 304 with thickness $\mathrm{a}_{0}=0.8 \mathrm{~mm}$ (Table 1). Surface roughness parameters Ra, Rz, and RPc (peak count per $\mathrm{cm}$ ) were measured according to the ISO 4287 standard in 10 different places on the sheet by a Mitutoyo Surftest SJ-301 device (Mitutoyo, Kawasaki, Kanagawa, Japan) in the rolling direction according to ISO 4287 with input values set to $\lambda \mathrm{c}=0.25 \mathrm{~mm}$ and $n=5$. Average values and the standard deviation for each parameter are shown in Table 1 . The roughness profile and Abbott-Firestone curve (bearing area curve) are shown in Figure 2.

Table 1. Surface roughness parameters for steels DC 05 and AISI 304.

\begin{tabular}{cccc}
\hline & $\boldsymbol{R a}(\boldsymbol{\mu m})$ & $\boldsymbol{R z}(\boldsymbol{\mu m})$ & $\left.\mathbf{R P c}_{(\mathbf{c m}}{ }^{\mathbf{1}}\right)$ \\
\hline DC 05 & $0.71 \pm 0.135$ & $5.04 \pm 0.604$ & $120.7 \pm 35.2$ \\
\hline AISI 304 & $0.07 \pm 0.020$ & $0.60 \pm 0.189$ & $241.1 \pm 72.3$ \\
\hline
\end{tabular}


(a)
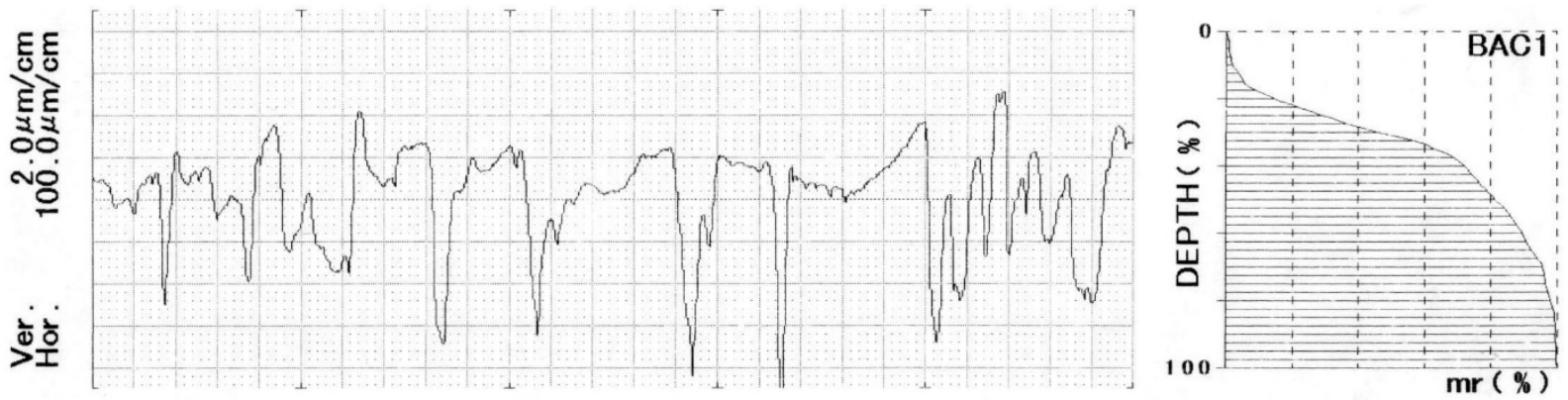

(b)
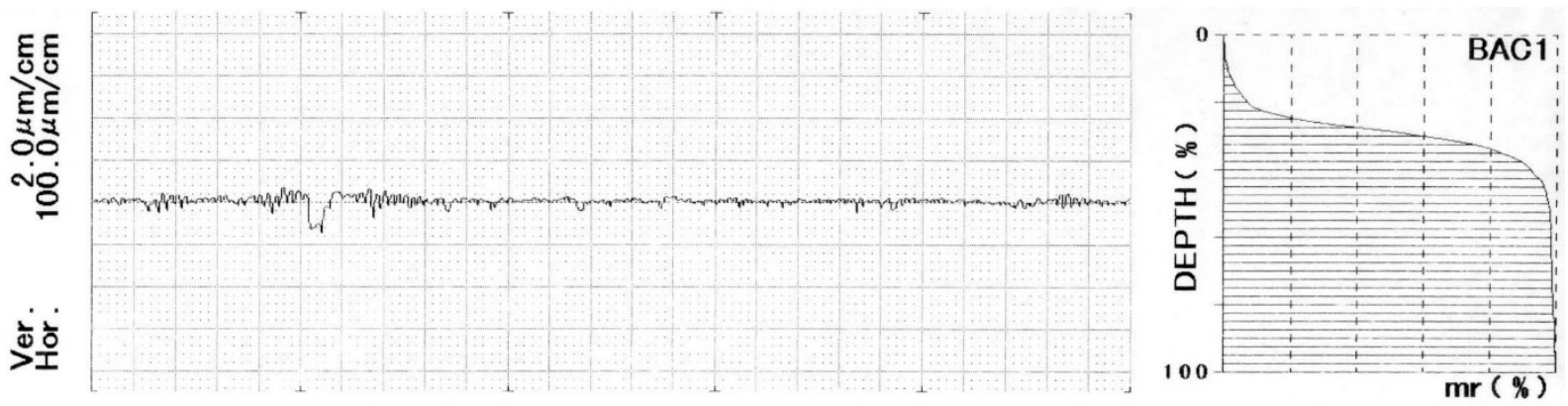

Figure 2. Roughness profile and Abbot-Firestone curve; (a) DC 05, and (b) AISI 304.

Mechanical properties were measured by ISO 6892-1, normal anisotropy ratios by ISO 10113 at a strain level of 20\%, and strain-hardening exponents by ISO 10275 within the strain range $5-20 \%$. A PC-controlled TiraTEST 2300 (TIRA GmbH, Schalkau, Germany) testing machine with extensometers for length and width measurement was used with automated evaluation of the properties shown in Table 2. The chemical composition of both materials is in Table 3.

Table 2. Mechanical properties of steels.

\begin{tabular}{|c|c|c|c|c|c|c|}
\hline Title 1 & $\begin{array}{l}\text { Dir } \\
\left({ }^{\circ}\right)\end{array}$ & $\begin{array}{c}\mathrm{R}_{\mathrm{p} 0 \cdot 2} \\
(\mathrm{MPa})\end{array}$ & $\begin{array}{c}\mathrm{Rm} \\
(\mathrm{MPa})\end{array}$ & $\begin{array}{c}\mathrm{K} \\
(\mathrm{MPa})\end{array}$ & $\begin{array}{l}n \\
(-)\end{array}$ & $\begin{array}{l}r \\
(-)\end{array}$ \\
\hline \multirow{3}{*}{ DC 05} & 0 & 164 & 299 & 505 & 0.23 & 1.9 \\
\hline & 45 & 172 & 309 & 531 & 0.219 & 1.5 \\
\hline & 90 & 166 & 296 & 511 & 0.221 & 2.2 \\
\hline \multirow{3}{*}{ AISI 304} & 0 & 267 & 634 & 1523 & 0.517 & 0.98 \\
\hline & 45 & 262 & 615 & 1469 & 0.519 & 1.03 \\
\hline & 90 & 273 & 629 & 1491 & 0.515 & 0.99 \\
\hline
\end{tabular}

Notes: Dir-rolling direction; $\mathrm{R}_{\mathrm{p} 0 \cdot 2}$-yield stress; $\mathrm{Rm}$-ultimate tensile stress; $\mathrm{K}$-strength constant; $\mathrm{n}$ strainhardening exponent; $r$ - plastic strain ratio.

Table 3. Chemical composition of steels (in weight \%).

\begin{tabular}{|c|c|c|c|c|c|c|c|c|c|c|c|c|c|c|c|}
\hline & $\mathrm{C}$ & Mn & $\mathrm{Si}$ & $\mathbf{P}$ & $S$ & Al & $\mathrm{Nb}$ & $\mathrm{Ti}$ & $\mathrm{Cu}$ & $\mathrm{Cr}$ & Mo & $\mathrm{Ni}$ & $\mathbf{V}$ & Co & W \\
\hline DC 05 & 0.03 & 0.18 & 0.01 & 0.009 & 0.01 & 0.044 & 0.003 & 0.002 & - & - & - & - & - & - & - \\
\hline AISI 304 & 0.055 & 1.597 & 0.592 & 0.018 & $<0.002$ & 0.009 & 0.049 & 0.007 & 0.029 & 18.3 & 0.015 & 7.79 & 0.04 & 0.062 & 0.015 \\
\hline
\end{tabular}

The friction simulator shown in Figure 3 was used to study the friction in a stamping process. This simulator enables modelling the stress state of flat (Figure 1a) and curved regions (Figure $1 \mathrm{~b}$ ). Processes on the contact areas can be investigated separately or combined. The roller can be fixed or free rotated. If the movement of the roller is not blocked, the loading of the die contact areas under the blankholder between flat surfaces is being modelled (Figure 1a). In the case the roller is fixed, the loading of the curved contact areas on the die drawing edge is being modelled (Figure $1 \mathrm{~b}$ ). 


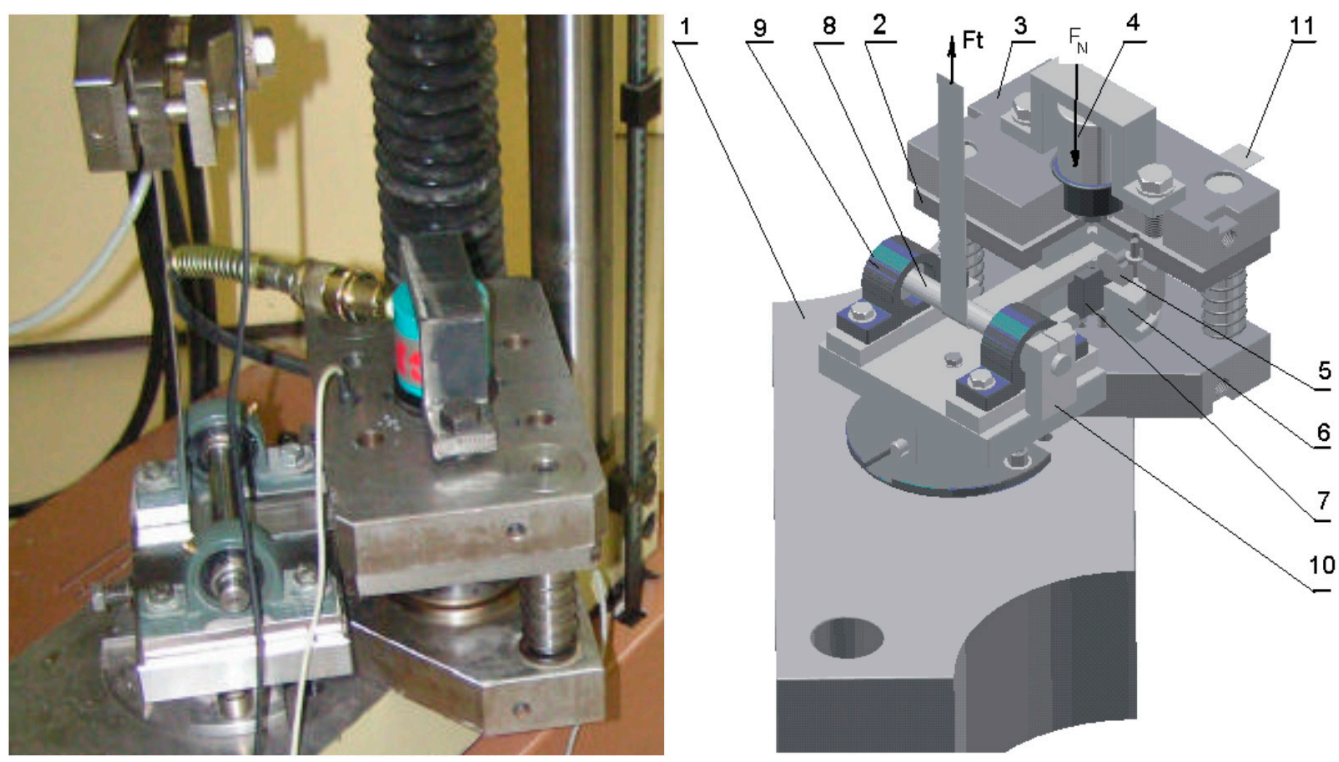

Figure 3. The friction simulator photo and CAD model-strip drawing test. 1-base plate; 2middle plate; 3-upper plate; 4-hydraulic clamping cylinder; 5-upper grip; 6-lower grip; 7dynamometer for measurement of blankholding force; 8-roller; 9-ball bearings; 10 — brake mechanism of the roller; 11-strip.

Drawing conditions were as follows: Blankholding forces $\mathrm{F}_{\mathrm{N}}=2,3,4,6$, and $8 \mathrm{kN}$, strip drawing speed $\mathrm{v}=10 \mathrm{~mm} / \mathrm{s}$, strip width $50 \mathrm{~mm}$, grips' contact area $20 \times 50 \mathrm{~mm}$. Both, grips and roller of friction tester were made from tool steel 1.2379, hardened to $63 \mathrm{HRc}$ and polished to $\mathrm{Ra}=0.32 \pm 0.05 \mu \mathrm{m}$. The surface of the sheet strip was lubricated with Anticorit Prelube $3802-39 \mathrm{~S}$ lubricant with a kinematic viscosity of $60 \mathrm{~mm}^{2} \cdot \mathrm{s}^{-1}$ at $40{ }^{\circ} \mathrm{C}$ in the amount of $2 \mathrm{~g} \cdot \mathrm{m}^{-2}$. During the strip drawing test, drawing force and blankholding force were measured. The measuring system consisted of KAS 20 and KF $20 \mathrm{~K}$ force load cells, a QuantumX MX440A tensometric measuring unit (HBM, Darmstadt, Germany) and Catman Easy software (HBM, Darmstadt, Germany).

A record of the drawing and blankholding forces is shown in Figure 4. From experimentally-measured values of the drawing and blankholding forces the friction coefficient can be determined in the area under the blankholder and on the die drawing edge as well. Two methods were applied for evaluation of friction coefficient in the area under the blankholder.

In the first method the regression analysis was used [5,18-20]. The relation between the blankholding force and drawing force can be described as follows:

$$
\Delta \mathrm{F}_{p(\mathrm{f} 3=0)}=\text { Intercept }+\Delta \mathrm{F}_{\mathrm{N} 1,2}(\text { Slope })
$$

where $\Delta \mathrm{F}_{\mathrm{p}(\mathrm{f} 3=0)}$ is the difference of drawing forces versus the difference of blankholding forces; $\Delta \mathrm{F}_{\mathrm{N} 1,2}$ is difference of the blanholding forces $\mathrm{F}_{\mathrm{N} 2}-\mathrm{F}_{\mathrm{N} 1}, \mathrm{~F}_{\mathrm{N} 2}>\mathrm{F}_{\mathrm{N} 1}$; $\left(\mathrm{F}_{\mathrm{N} 2}\right.$ blankholding force for current measurement, $\mathrm{F}_{\mathrm{N} 1}$ - blankholding force for previous measurement; for the first measurement it is not possible to calculate). 


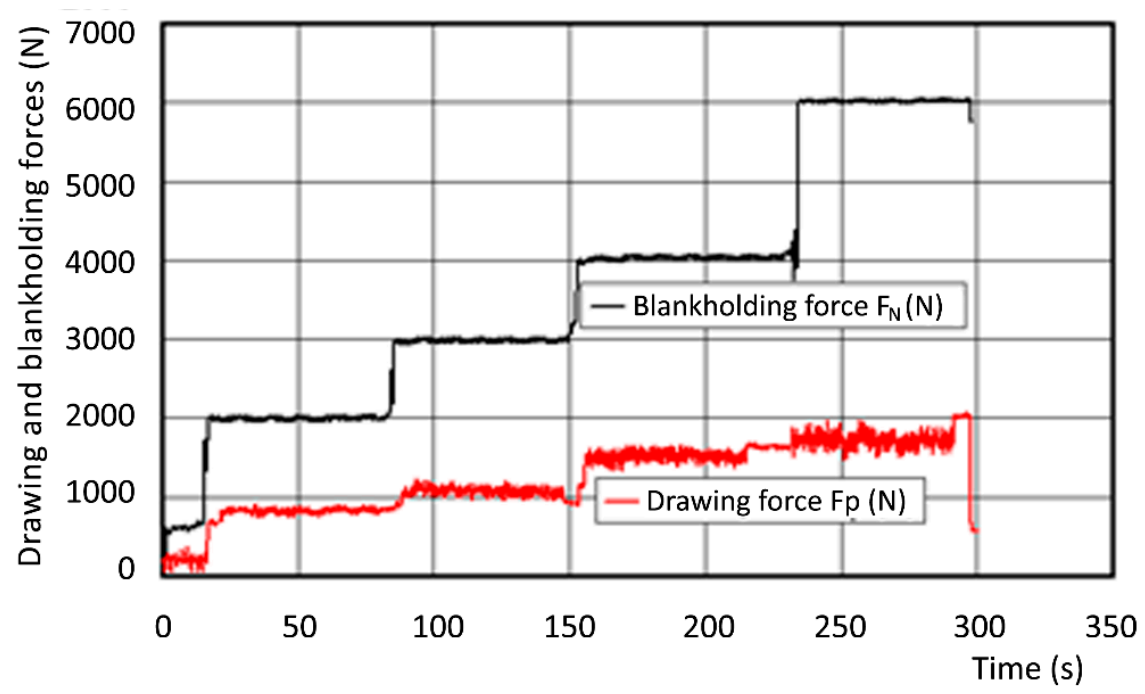

Figure 4. Record of the drawing and blankholding forces in the strip drawing test.

It is known that increasing the blankholding force results in an increase of the drawing force. Thus, the friction coefficient $\mathrm{f}_{1,2}$ is calculated as half value of slope:

$$
\mathrm{f}_{1,2}=\frac{\text { Slope }}{2}
$$

where $\mathrm{f}_{1,2}$-mean friction coefficient between die and strip.

The second method emerges from analytical models based on the measurement of forces during the strip drawing test [19]. When the roller on the friction simulator is not blocked (friction model under the blankholder), the friction coefficient $\mathrm{f}_{1,2}$ is calculated as follows:

$$
\mathrm{f}_{1,2}=\frac{\mathrm{F}_{\mathrm{p} 2(\mathrm{f} 3=0)}-\mathrm{F}_{\mathrm{p} 1, \mathrm{ref}(\mathrm{f} 3=0)}}{2\left(\mathrm{~F}_{\mathrm{N} 2}-\mathrm{F}_{\mathrm{N} 1, \mathrm{ref}}\right)}=\Delta \mathrm{F}_{\mathrm{p} 1,2(\mathrm{f} 3=0)} /\left(2 \Delta \mathrm{F}_{\mathrm{N} 1,2}\right)
$$

where $F_{\mathrm{bA}}$ is the bending force, $\mathrm{F}_{\mathrm{N} 1 \text {,ref }}=2 \mathrm{kN}, \mathrm{F}_{\mathrm{N} 2}$ is the blankholding force $\left(\mathrm{F}_{\mathrm{N} 1 \text {,ref }}<\right.$ $\left.\mathrm{F}_{\mathrm{N} 2}\right), \mathrm{F}_{\mathrm{p} 2(\mathrm{f} 3=0)}$ is drawing force generated by the blankholding force $F_{\mathrm{N} 2}, \mathrm{~F}_{\mathrm{p} 1 \text {, ref }(\mathrm{f} 3=0)}$ is the drawing force generated by the blankholding force $\mathrm{F}_{\mathrm{N} 1 \text {,ref }}$.

When the roller on the friction simulator is blocked (friction model on the die drawing edge), the friction coefficient $f_{3}$ is calculated as follows:

$$
\mathrm{f}_{3}=\ln \left(\frac{\mathrm{F}_{\mathrm{p}(\mathrm{f} 3>0)}}{\mathrm{F}_{\mathrm{p}(\mathrm{f} 3=0)}}\right) \frac{2}{\pi}
$$

where $F_{p(f 3=0)}$ is the drawing force generated by a rotating roller, $F_{p(f 3>0)}$ is the drawing force generated by a fixed roller, and $\mathrm{f}_{3}$ is the friction coefficient in the die drawing edge.

The cup test was performed on a hydraulic machine RM-501 LVH-1. The test parameters were as follows: the punch diameter $\mathrm{d}=32.85 \mathrm{~mm}$, the punch radius $\mathrm{r}_{\mathrm{p}}=4.5 \mathrm{~mm}$, the die radius $r_{d}=4.5 \mathrm{~mm}$, the roughness of the die and blankholder $R a=0.4 \mu \mathrm{m}$, and the amount of lubricant was $2 \mathrm{~g} \cdot \mathrm{m}^{-2}$. Sheet blanks with diameter $\mathrm{D}_{0}=60 \mathrm{~mm}$ were used for studying various contact conditions. Blankholder forces $\mathrm{F}_{\mathrm{N}}$ were set as follows: $\mathrm{F}_{\mathrm{N}}=2$; $5 ; 10,20$, and $30 \mathrm{kN}$. The drawing force measurement under the same conditions was performed on five specimens (Figure 5). 


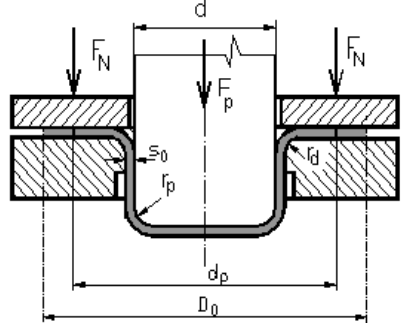

(a)

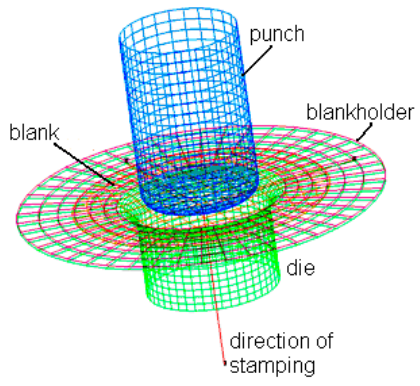

(b)

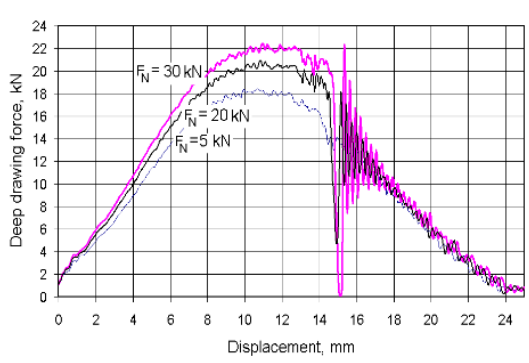

(c)

Figure 5. Cup test: (a) Scheme, (b) simulation model, (c) course of force for DC 05, $f=0.1$.

To verify the measured values of the friction coefficient, numerical simulation of the cup test was done in Pam Stamp 2G software (ESI Group, Rungis, France). The friction coefficients in the simulations were set as calculated by analytical models based on the results of the strip drawing test. The value of friction coefficient $f_{1,2}$ was set under the blankholder and the value of the friction coefficient $f_{3}$ was set on the drawing edge.

Data of the process parameters (punch and die geometry, blank diameter, blankholder forces) were the same as during the experiment. The material model to describe elastic properties of the blank consisted of the Young's modulus E $=210 \mathrm{GPa}$ and Poisson's ratio $v=0.3$. Constitutive material equations describe material behavior beyond the yield stress. These are described by the Hill 48 yield law (i.e., the yield stress under the plane strain condition) and Hollomon's hardening law describing the hardening curve beyond yielding. Hollomon's hardening law approximated from the tensile test record and is defined as follows:

$$
\sigma_{\text {true }}=\mathrm{K} \cdot \varphi^{\mathrm{n}}
$$

where $\mathrm{K}$ is the material constant, and $\mathrm{n}$ is the strain-hardening exponent (see Table 2), and the Hill 48 yield criterion was defined for principal stresses and considering anisotropy as follows [21-24]:

$$
\sigma_{\mathrm{Y}}^{2}=\sigma_{1}^{2}-\left(\frac{2 \cdot \mathrm{r}_{0}}{1+\mathrm{r}_{0}}\right) \cdot \sigma_{1} \cdot \sigma_{2}+\frac{\mathrm{r}_{0}}{\mathrm{r}_{90}} \cdot\left(\frac{1+\mathrm{r}_{90}}{1+\mathrm{r}_{0}}\right) \cdot \sigma_{2}^{2}
$$

where $\sigma_{Y}$ is the yield stress, $r_{0}$ and $r_{90}$ are the plastic strain ratios in $0^{\circ}$ and $90^{\circ}$ to the rolling direction, and $\sigma_{1}$ and $\sigma_{2}$ are the major and minor stresses. As a result, the drawing force course under various blankholding forces were found and the maximum drawing forces were evaluated. These were compared to those experimentally measured.

\section{Results and Discussion}

\subsection{Strip Test}

Table 4 shows the values of blankholding forces $\mathrm{F}_{\mathrm{N}}$ set during experiments and the measured values of drawing forces $F_{p(f 3=0)}$ and $F_{p(f 3>0)}$ during the strip drawing test. The friction coefficient under the blankholder is evaluated by the regression analysis (the first method-Equations (1) and (2)), as is shown in Figure 6. The friction coefficient $f_{1,2}$ for experimental materials calculated according to Equation (2) was $\mathrm{f}_{1,2}=0.11 \pm 0.012$, with $\mathrm{R}^{2}=0.993$ for DC 05 and $\mathrm{f}_{1,2}=0.23 \pm 0.049$ with $\mathrm{R}^{2}=0.997$ for AISI 304 steel. 


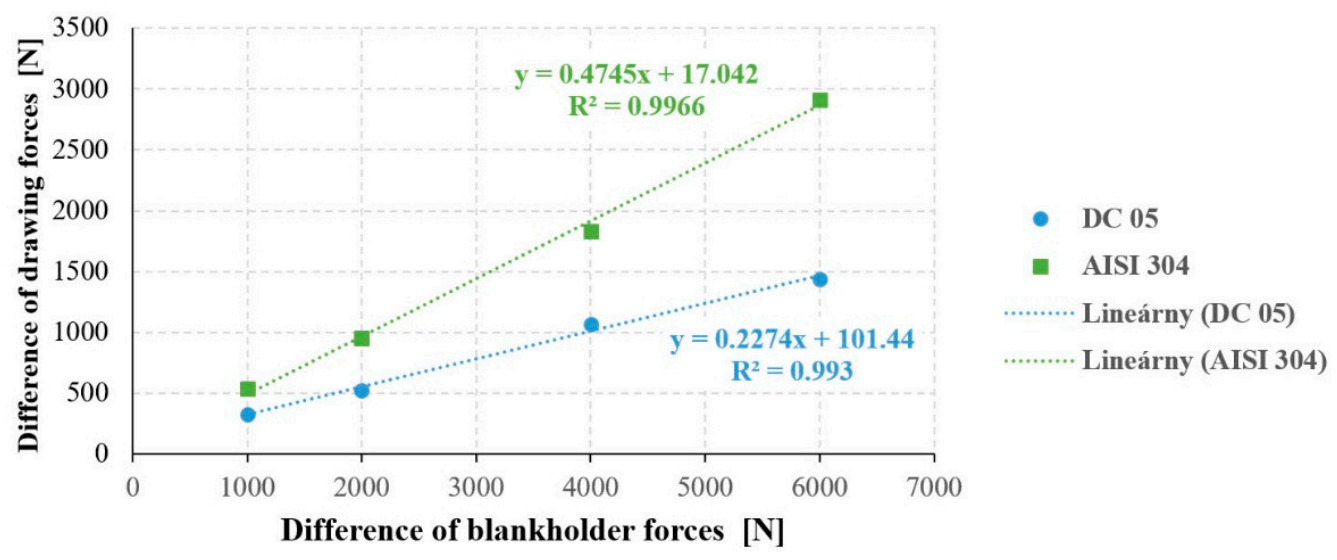

Figure 6. Evaluation of the friction coefficient by linear regression.

Table 4. Measured values of forces and calculated values of friction coefficient.

\begin{tabular}{|c|c|c|c|c|c|c|c|}
\hline \multirow[b]{2}{*}{ Material } & \multirow{2}{*}{$\begin{array}{l}\text { Normal } \\
\text { Force } \\
\text { F }_{\mathrm{N}}(\mathbf{k N})\end{array}$} & \multirow{2}{*}{$\begin{array}{l}\text { Specific } \\
\text { Pressure } \\
\text { p (MPa) }\end{array}$} & \multicolumn{2}{|c|}{ Drawing Force $F_{p}(N)$} & \multicolumn{3}{|c|}{ Friction Coefficient $\mathbf{f}(-)$} \\
\hline & & & $\mathbf{f}_{3}=0$ & $\mathrm{f}_{3}>0$ & $\begin{array}{c}\mathbf{f}_{1,2} \\
\text { Equation (2) }\end{array}$ & $\begin{array}{c}\mathbf{f}_{1,2} \\
\text { Equation (3) }\end{array}$ & $\begin{array}{c}f_{3} \\
\text { Equation (4) }\end{array}$ \\
\hline \multirow{5}{*}{ DC 05} & 2 & 1.3 & 673 & 816 & \multirow{5}{*}{$\begin{array}{c}0.11 \\
\pm 0.012\end{array}$} & - & 0.123 \\
\hline & 3 & 2.0 & 970 & 1176 & & 0.149 & 0.123 \\
\hline & 4 & 2.7 & 1142 & 1400 & & 0.117 & 0.120 \\
\hline & 6 & 4.0 & 1654 & 1977 & & 0.123 & 0.139 \\
\hline & 8 & 5.3 & 1993 & 2367 & & 0.110 & 0.117 \\
\hline \multirow{5}{*}{ AISI 304} & 2 & 1.3 & 1398 & 1860 & \multirow{5}{*}{$\begin{array}{c}0.23 \\
\pm 0.049\end{array}$} & - & 0.182 \\
\hline & 3 & 2.0 & 1779 & 2550 & & 0.191 & 0.229 \\
\hline & 4 & 2.7 & 2145 & 3017 & & 0.187 & 0.217 \\
\hline & 6 & 4.0 & 2930 & 3995 & & 0.192 & 0.197 \\
\hline & 8 & 5.3 & 3808 & 5282 & & 0.201 & 0.208 \\
\hline
\end{tabular}

When the friction coefficient under the blankholder $\mathrm{f}_{1,2}$ and on the drawing edge $\mathrm{f}_{3}$ were evaluated by the analytical model according to Equations (3) and (4), respectively, the values varied from 0.149 to 0.11 for the friction coefficient under the blankholder $\mathrm{f}_{1,2}$ and from 0.139 to 0.117 for the friction coefficient on the drawing edge $f_{3}$ for DC 05 material. It can be seen that by increasing the pressure of the blankholder from 2 to $5.3 \mathrm{MPa}$ (except $4 \mathrm{MPa}$ ) there was a slight reduction in the friction coefficient. This reduction in the friction coefficient is strengthened by using Anticorit 3802-39 S lubricant with a high-pressure additives (EP). The effectiveness of EP additives increases with the increasing pressure on the contact surfaces.

When material AISI 304 was applied, the unambiguous tendency was not recordedthe friction coefficient under the blankholder $\mathrm{f}_{1,2}$ evaluated by the analytical model according to Equation (3) varied from 0.201 to 0.187 and the friction coefficient on the drawing edge $f_{3}$ evaluated by the analytical model according to Equation (4) varied from 0.229 to 0.197 (Figure 7). It is assumed that lubricant during drawing the strip was not retained well on the contact surfaces because the blank surface was very smooth $(\mathrm{Ra}=0.07 \pm 0.02 \mu \mathrm{m})$. This also correlates to the Abbott-Firestone curve (bearing area curve) and the roughness profile are shown in Figure 2. 


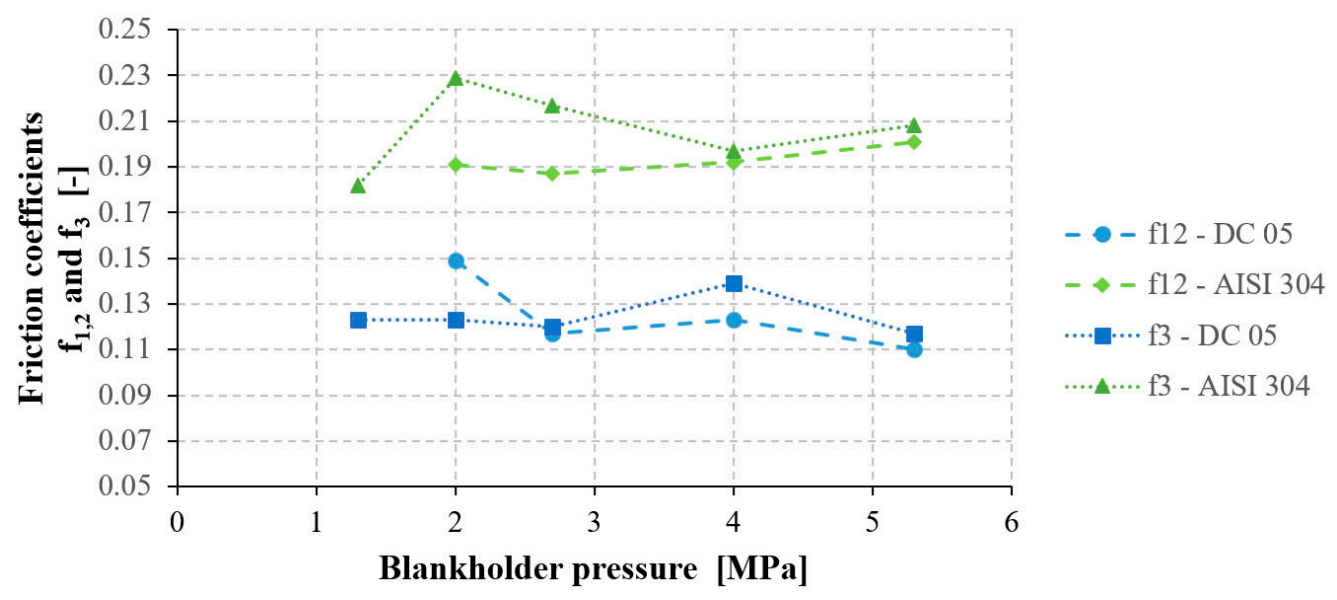

Figure 7. Dependence of friction coefficient $\mathrm{f}_{1,2}$ on the blankholder pressure.

\subsection{Numerical Simulation of the Cup Test}

Results of the cup test evaluated as the relationships of the experimentally-measured drawing forces versus blankholding forces are shown in Figure 8. The slopes of the dependent drawing force to the blankolding force express the values of friction coefficients $\mathrm{f}_{\mathrm{m}}, \mathrm{f}_{\mathrm{c}}$ as is shown in Table 5 .

Table 5. Comparison of experimentally measured $\mathrm{F}_{\mathrm{pm}}$ and calculated $\mathrm{F}_{\mathrm{pc}}$ values for drawing forces.

\begin{tabular}{cccccccccc}
\hline Material & $\mathbf{F}_{\mathbf{N}}(\mathbf{k N})$ & $\mathbf{2}$ & $\mathbf{5}$ & $\mathbf{1 0}$ & $\mathbf{2 0}$ & $\mathbf{3 0}$ & Linear Regression & $\mathbf{f}_{\mathbf{m}}$ & $\mathbf{f}_{\mathbf{c}}$ \\
\hline \multirow{5}{*}{ DC 05 } & $\mathrm{F}_{\mathrm{pm}}(\mathrm{kN})$ & 19.08 & 19.91 & 21.08 & 23.2 & 24.8 & $18.88+0.204 \times \mathrm{F}_{\mathrm{N}}$ & 0.102 & - \\
& $\mathrm{F}_{\mathrm{pc}}(\mathrm{kN})$ & 17.5 & 18.41 & 19.23 & 20.92 & 22.45 & $17.40+0.172 \times \mathrm{F}_{\mathrm{N}}$ & - & 0.086 \\
& $\Delta \mathrm{F}_{\mathrm{P}(\mathrm{m}-\mathrm{c})}(\mathrm{kN})$ & 1.58 & 1.5 & 1.85 & 2.28 & 2.35 & & & \\
& $\Delta \mathrm{F}_{\mathrm{P}(\mathrm{m}-\mathrm{c})}(\%)$ & 8.28 & 7.53 & 8.78 & 9.83 & 9.48 & & & \\
\hline \multirow{5}{*}{ AISI 304 } & $\mathrm{F}_{\mathrm{pm}}(\mathrm{kN})$ & 28.56 & 29.21 & 31.4 & 35.22 & 39.54 & $27.46+0.397 \times \mathrm{F}_{\mathrm{N}}$ & 0.199 & - \\
& $\mathrm{F}_{\mathrm{pc}}(\mathrm{kN})$ & 24.55 & 25.7 & 26.8 & 30.33 & 34.02 & $23.79+0.335 \times \mathrm{F}_{\mathrm{N}}$ & \\
& $\Delta \mathrm{F}_{\mathrm{P}(\mathrm{m}-\mathrm{c})}(\mathrm{kN})$ & 4.01 & 3.51 & 4.6 & 4.89 & 5.52 & & & \\
& $\Delta \mathrm{F}_{\mathrm{P}(\mathrm{m}-\mathrm{c})}(\%)$ & 14.04 & 12.02 & 14.65 & 13.88 & 13.96 & & & \\
\hline
\end{tabular}

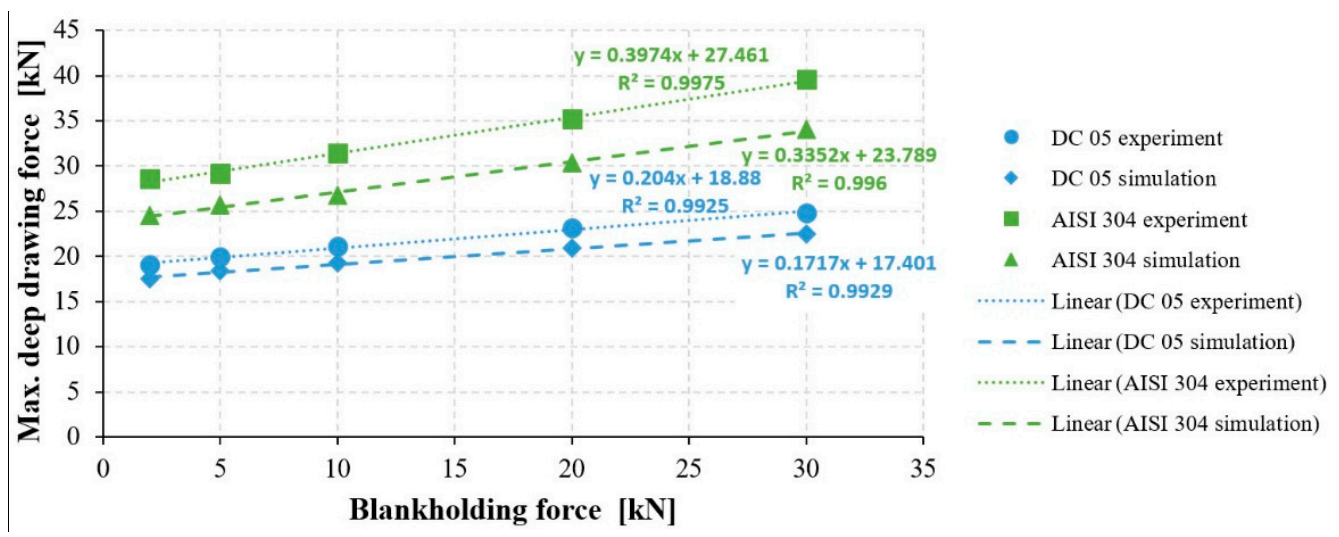

Figure 8. Drawing forces to blankholding forces dependence in the cup test.

Comparing friction coefficients $\mathrm{f}_{1,2}$ determined by the friction simulator (Table 4 ) and the friction coefficient values $\mathrm{f}_{\mathrm{m}}$ determined by the cup test (Table 5) resulted in good conformity for material DC 05 with a difference $\Delta \mathrm{f}=0.008$. However, there is a higher difference $\Delta \mathrm{f}=0.03$ for material AISI 304, even though it is within the error of measurement.

When comparing the results of the cup test and numerical simulations of the cup test, there is good conformity for material DC 05 with difference $\Delta f=0.016$, but the difference for material AISI 304 is higher $\Delta \mathrm{f}=0.031$ (Table 6). Considering it is the austenitic stainless 
steel, different hardening models should be used in the numerical simulation because they affect the maximum force in the cup test $[25,26]$.

Table 6. Comparison of friction coefficients in the cup test from measured (experiment) and calculated (simulation) values of drawing forces.

\begin{tabular}{ccccc}
\hline & $\begin{array}{l}\text { Strip Drawing Test } \\
\mathbf{f}_{\mathbf{1 , 2}}(-) \text { Equation (2) }\end{array}$ & $\mathbf{f}_{\mathbf{m}}(-)$ & $\mathbf{f}_{\mathbf{c}}(-)$ & $\Delta \mathbf{f}=\mathbf{f}_{\mathbf{m}}-\mathbf{f}_{\mathbf{c}}$ \\
\hline Material & $0.11 \pm 0.012$ & 0.102 & 0.086 & 0.016 \\
DC 05 & $0.23 \pm 0.049$ & 0.199 & 0.168 & 0.031 \\
AISI 304 & & & & \\
\hline
\end{tabular}

\subsection{Discussion}

Numerical simulations of stamping are sensitive to the exact description of boundary conditions and constitutive equations (yield curve and hardening law) describing material behavior during plastic deformation. In the numerical simulation of the cup test the Hill 48 yield law and Hollomon hardening law were used because of their simple constitution from tensile test data (Table 2). Are they adequate enough to describe material behavior and the tendency to increase the maximal drawing force when increasing the blankholder force?

Neto [27] investigated the effect of the yield criterion (von Mises, Hill 48, and Barlat Yield 91) combined with the Swift hardening law on the numerical results of redrawing the mild steel. Predicted punch force evolution was close to the experimental one, whatever the yield criterion adopted. Nevertheless, the cup wall thickness distribution was strongly influenced by the yield criteria, being clearly overestimated by the von Mises yield criterion. The same result was reached by Amaral [28] when studying the effect of anisotropic yield criteria (Hill 48, Barlat 91, and CPB06) during deep drawing of a cylindrical cup from advanced high-strength steels.

In the presented study the predicted maximum forces are lower than the measured one as shown in Table 5. It agrees with [27], where the numerically-simulated force evolution for the 1st stage (cup drawing) was slightly lower than the experimental one for each yield law studied. Thus, from the view of yield laws, the numerically-predicted punch force in the presented study is not influenced by the yield law.

When concerning the hardening law, da Silva [29] evaluated different models, such as Hollomon, Swift, Voce, Ludwick, Misiolek, and Ramberg-Osgood, to determine which best represented the plastic behavior of austenitic (304) and ferritic (439A) stainless steels. They evaluated stress-strain curves obtained from tensile tests and the Ludwik law fit best for the austenitic stainless steel, while Swift fit best for ferritic stainless steel. Sener [30] also determined that the Ludwik hardening model was the best fit to the experimental data when they studied the influence of hardening model to the thickness distribution of a rectangular cup from AISI 304 stainless steel. Although the trend of thickness distribution predicted by the simulation matched with the experiment, more thinning was observed in the simulation than in the experiments.

The comparison of stress-strain curves of Hollomon's hardening law for materials used in this study is presented in Figure 9. It is clear that higher strains are predicted for stainless steel AISI 304 due to higher value of the strain hardening exponent (Table 2). Considering it is the austenitic stainless steel and the nature of its plastic deformation, other phenomena should be included in explaning the deformation process of this steel, such as adiabatic deformation. This is because the dominant material variable that determines whether or not adiabatic shearing deformation will occur is undoubtedly the rate of workhardening of the material [31]. The simulation software and hardening law, and others presented in previous sections as well, do not include this phenomena, so that might explain the higher difference in drawing forces measured experimentally to those numerically calculated for austenitic stainless steel. 


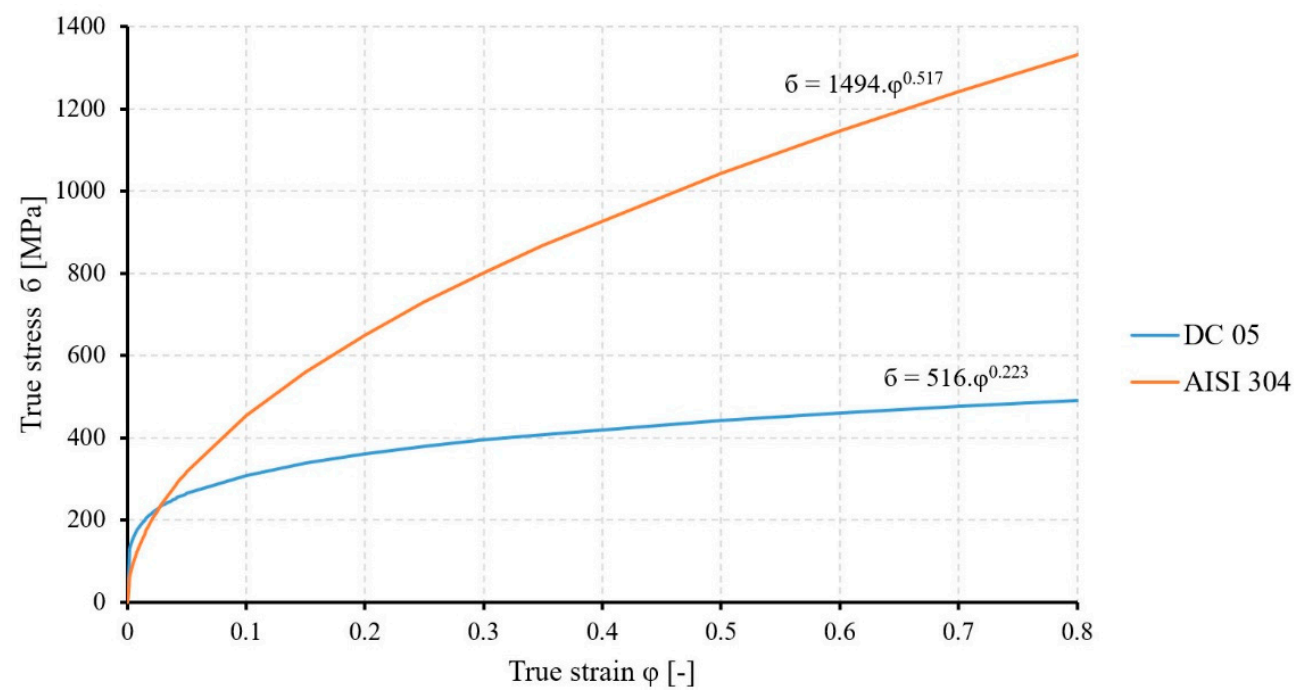

Figure 9. Comparison of hardening laws for experimental materials.

It might be concluded that the results of the cup test simulations presented in this study are valid even for the Hollomon's hardening law used. It is supported by the fact that the tendency of the maximum drawing force increasing (Table 5) is the same as for the experiment. When comparing the tendency of the maximal drawing force, the difference is the same- $7.53 \%$ to $9.83 \%$ for DC 05 steel and $12.02 \%$ to $14.65 \%$ for AISI 304 . This means the drawing force increases almost the same increment for each blankholding force. Thus, the tendency of increasing the maximum drawing forces numerically calculated is not influenced by the material constitutive equation. This finding is also supported by the regression coefficients $R^{2}$ when they are compared to the experimentally-measured values and numerically determined: for DC 05 they are 0.9925 (experiment) and 0.9929 (simulation) and for AISI 304 they are 0.9975 (experiment) and 0.996 (simulation).

\section{Conclusions}

Modern analytic methods allow for calculating different values of the friction coefficient in different regions of contact surfaces between the die and the blank-under the blankholder and on the drawing edge. These can be used in FEM modelling of stamping processes. In the paper strip drawing test was performed for uncoated extra deep drawing quality steel DC 05 and austenitic stainless steel AISI 304. The friction coefficients were determined by two methods, the first based on linear regression and the second based on analytical models. Thus, the friction coefficient under the blankholder and on the die drawing edge were calculated. The results were verified by a cup test performed experimentally and numerically.

Based on the strip drawing test and cup test (experiment and numerical simulation), the following outputs were illustrated:

(a) Applying the linear regression model, the friction coefficient equals half of the slopes of dependence the difference of drawing forces to the difference of blankholding forces. Values of the friction coefficient in the area under the blankholder were $f_{1,2}=0.11$ for uncoated extra deep drawing quality steel DC05 and $\mathrm{f}_{1,2}=0.23$ for austenitic stainless steel AISI 304.

(b) Applying analytical models, the friction coefficients under the blankholder and on the drawing edge were not constant for different loading of the contact surfaces when measured for material DC05. The results obtained indicate that, with increased loading on the contact surfaces, the effectiveness of Anticorit 3802-39 S lubricant with high-pressure EP additives improves. The results obtained show that for the calculation of the friction coefficient the analytical model appears to be more suitable than the linear regression model. 
(c) The unambiguous tendency was not recorded for material AISI 304. It is assumed that lubricant during drawing the strip was not retained well on the contact surfaces because the steel sheet surface was very smooth $(\mathrm{Ra}=0.07 \pm 0.02 \mu \mathrm{m})$. This resulted in cold weld formation between the sheet surface and the roller even for lower pressures and shorter paths of drawing.

(d) The applied friction model in the FEM simulation was verified experimentally by a cup test. The difference $\Delta \mathrm{f}$ between friction coefficients $\mathrm{f}_{\mathrm{m}}$ determined from experimentally-measured forces and $\mathrm{f}_{\mathrm{c}}$ determined from calculated forces by FEM simulation was higher for material AISI 304. This is due to the material model definition used in the numerical simulation.

Author Contributions: Conceptualization: E.E. and N.D.; methodology: E.E., N.D., and A.M.; software: E.E. and A.M.; validation: E.E., N.D., and M.T.; formal analysis: M.T. and K.P.; investigation: K.P.; resources: E.E., N.D., A.M., and M.T.; data curation: A.M. and M.T.; writing-original draft preparation: K.P. and M.T.; writing—review and editing: K.P. and M.T.; visualization: A.M. and M.T.; supervision: E.E.; project administration: K.P.; funding acquisition: N.D. All authors have read and agreed to the published version of the manuscript.

Funding: This research was funded by the Scientific Grant Agency of the Ministry of Education of the Slovak Republic (projects VEGA 2/0800/19, KEGA 032EU-4/2020, and APVV-17-0381 a).

Institutional Review Board Statement: Not applicable.

Informed Consent Statement: Not applicable.

Data Availability Statement: The data presented in this study are available on request from the corresponding author.

Conflicts of Interest: The authors declare no conflict of interest. The funders had no role in the design of the study; in the collection, analyses, or interpretation of data; in the writing of the manuscript, or in the decision to publish the results.

\section{References}

1. Davies, G. Materials for Automobile Bodies; Elsevier: Butterworth-Heinemann, UK, 2003.

2. Bilík, J.; Titel, V.; Dobisova, M.; Suba, R. Formability of CP-W 800 steel sheets. Res. Pap. FMSaT Trnava Slovak Univ. Technol. Bratisl. 2009, 27, 15-20.

3. Mahrenholtz, O.; Bontcheva, N.; Iankov, R. Influence of surface roughness on friction during metal forming processes. J. Mater. Process. Technol. 2005, 159, 9-16. [CrossRef]

4. Solfronk, P.; Sobotka, J.; Korecek, D.; Kolnerova, M. Tribological properties of al-alloy designed for drawing stampings in automotive industry. MM Sci. J. 2018, 2354-2357. [CrossRef]

5. Hrivnak, A.; Evin, E. Formability of Steel Sheets, 1st ed.; Elfa: Košice, Slovakia, 2004.

6. Ceretti, E.; Fiorentino, A.; Giardini, C. Process parameters influence on friction coefficient in sheet forming operations. Int. J. Mater. Form. 2008, 1, 1219-1222. [CrossRef]

7. Başpınar, M.; Akkök, M. Modeling and Simulation of Friction in Deep Drawing. J. Tribol. 2016, 138. [CrossRef]

8. Hassan, M.A.; Ahmed, K.; Takakura, N. A developed process for deep drawing of metal foil square cups. J. Mater. Process. Technol. 2012, 212, 295-307. [CrossRef]

9. Sniekers, R.J.J.M.; Smits, H.A.A. Experimental set-up and data processing of the radial strip-drawing friction test. J. Mater. Process. Technol. 1997, 66, 216-223. [CrossRef]

10. Vollertsen, F.; Zhenyu, H. Determination of size-dependent friction functions in sheet metal forming with respect to the distribution of the contact pressure. Prod. Eng. 2008, 2, 345-350. [CrossRef]

11. Kirkhorn, L.; Frogner, K.; Andersson, M.; Ståhl, J.E. Improved Tribotesting for Sheet Metal Forming. Procedia CIRP 2012, 3 , 507-512. [CrossRef]

12. Wang, C.; Ma, R.; Zhao, J.; Zhao, J. Calculation method and experimental study of coulomb friction coefficient in sheet metal forming. J. Manuf. Process. 2017, 27, 126-137. [CrossRef]

13. Hol, J.; Cid Alfaro, M.V.; de Rooij, M.B.; Meinders, T. Advanced friction modeling for sheet metal forming. Wear 2012, 286-287, 66-78. [CrossRef]

14. Trzepieciński, T.; Fejkiel, R. On the influence of deformation of deep drawing quality steel sheet on surface topography and friction. Tribol. Int. 2017, 115, 78-88. [CrossRef]

15. Wang, B.Y.; Lei, F.U.; Zhou, J.; Huang, M.-D. Effect of friction coefficient in deep drawing of AA6111 sheet at elevated temperatures. Trans. Nonferr. Metals Soc. China 2015, 25, 2342-2351. 
16. Kott, M.; Erz, C.; Heingärtner, J.; Groche, P. Controllability of Temperature Induced Friction Effects during Deep Drawing of Car Body Parts with High Drawing Depths in Series Production. Procedia Manuf. 2020, 47, 553-560. [CrossRef]

17. Trzepieciński, T.; Lemu, H.G. Recent Developments and Trends in the Friction Testing for Conventional Sheet Metal Forming and Incremental Sheet Forming. Metals 2020, 10, 47. [CrossRef]

18. Antoszewski, B.; Evin, E.; Audy, J. A study of the effect of type (Cu+Ti) and (Mo+Ti) electro-spark coatings on friction in pin-on-disc testing. J. Tribol. 2008, 130, 0213031-0213036.

19. Evin, E.; Nemeth, S.; Vyrostek, M. Evaluation of Friction Coefficient of Stamping. Acta Mech. Slovaca 2014, 18, 20-27. [CrossRef]

20. Audy, J.; Evin, E. Exploring efficiency of tool coating via deep drawing of cylindrical cups. MM Sci. J. 2008, 6, 20-23. [CrossRef]

21. Vyboch, J.; Evin, E.; Kmec, J. Tribological Aspects of Numerical Simulation of Deep-Drawing Process. Manuf. Eng. 2011, 3, 38-41.

22. Pradeep Menezes, L.; Kumar, K.; Kishore, R.; Satish Kailas, V. Influence of friction during forming processes study using a numerical simulation technique. Int. J. Adv. Manuf. Technol. 2009, 40, 1067-1076. [CrossRef]

23. Schrek, A.; Švec, P.; Brusilová, A.; Gábrišová, Z. Simulation process deep drawing of tailor welded blanks DP600 and BH220 materials in tool with elastic blankholder. Stroj. Cas. 2018, 68, 95-102. [CrossRef]

24. Valeš, M.; Chrášt’anský, L.; Tatíček, F.; Pčák, T. Comparison of numerical simulation and deep drawing test of DP500 steel. In Proceedings of the Metal 2018, 27th International Conference on Metallurgy and Materials, Brno, Czech Republic, 23-25 May 2018; pp. 501-506.

25. Marques, A.E.; Prates, P.A.; Pereira, A.F.G.; Oliveira, M.C.; Fernandes, J.V.; Ribeiro, B.M. Performance Comparison of Parametric and Non-Parametric Regression Models for Uncertainty Analysis of Sheet Metal Forming Processes. Metals 2020, $10,457$. [CrossRef]

26. Kim, S.; Lee, J.; Barlat, F.; Lee, M.-G. Formability prediction of advanced high strength steels using constitutive models characterized by uniaxial and biaxial experiments. J. Mater. Process. Technol. 2013, 213, 1929-1942. [CrossRef]

27. Neto, D.M.; Oliveira, M.C.; Alves, J.L.; Menezes, L.F. Influence of the plastic anisotropy modelling in the reverse deep drawing process simulation. Mater. Des. 2014, 60, 368-379. [CrossRef]

28. Amaral, R.L.; Santos, A.D.; Miranda, S.S.; de Sa, J.C. Earing profile and wall thickness prediction of a cylindrical cup for dual-phase steels using different yield criteria in FE simul. AIP Conf. Proc. 2019, 2113, 180011-1-180011-6.

29. Da Silva, N.C.; Oliveira, S.A.G. Comparative study of the constitutive equations to predict work hardening characteristics of stainless steels 304 and ACE P439A. In Proceedings of the COBEM 2009, 20th International Congress of Mechanical Engineering, Gramado, Brazil, 15-20 November 2009; pp. 1-8.

30. Sener, B.; Kurtaran, H. Modeling the deep drawing of an AISI 304 stainless-steel rectangular cup using the finite-element method and an experimental validation. Mater. Technol. 2016, 50, 961-965. [CrossRef]

31. Rogers, H.C. Adiabatic plastic deformation. Annu. Rev. Mater. Sci. 1979, 9, 283-311. [CrossRef] 